\title{
Turboliquidatie: wat is een bate van de rechtspersoon in de zin van artikel 2:19 lid 4 BW?
}

\author{
Mr. H.J.de Kloe*
}

\begin{abstract}
Als het faillissement van een turbogeliquideerde rechtspersoon wordt aangevraagd, is het regelmatig van belang of de artikel 2:248 BW-vordering, de paulianavordering en de Peeters/Gatzen-vordering baten zijn van de rechtspersoon in de zin van artikel 2:19 lid 4 BW. Deze vraag wordt behandeld en er worden alternatieven aangereikt voor schuldeisers van een turbogeliquideerde rechtspersoon.
\end{abstract}

\section{Inleiding}

Het onderwerp turboliquidatie ${ }^{1}$ krijgt de laatste tijd in zowel de literatuur als de rechtspraak veel aandacht. ${ }^{2}$ Turboliquidatie is geregeld in artikel 2:19 lid 4 van het Burgerlijk Wetboek (BW). Op grond van artikel 2:19 lid 4 BW houdt een rechtspersoon op te bestaan als hij op het tijdstip van zijn ontbinding geen baten meer heeft. Het bestuur doet hiervan opgaaf aan het handelsregister. Een rechtspersoon die niet meer bestaat, kan niet failliet worden verklaard. Toch komt het in de praktijk geregeld voor dat om het faillissement van een turbogeliquideerde rechtspersoon wordt verzocht. De rechter moet dan toetsen of die rechtspersoon nog bestaat, omdat er nog een bate is in de zin van artikel 2:19 lid $4 \mathrm{BW}$. Als de rechtspersoon nog een bate heeft en voldaan is aan de (overige) voorwaarden, kan het faillissement worden uitgesproken. ${ }^{3}$

Mr. H.J. de Kloe is wetenschappelijk docent ondernemingsrecht en faillissementsrecht bij de sectie Handels- en Ondernemingsrecht \& Financieel Recht van de Erasmus School of Law te Rotterdam.

1. Quist stelt zich op het standpunt dat 'ontbinding zonder vereffening' of 'finale ontbinding' betere termen zijn voor turboliquidatie, zie P.H.N. Quist, Het T-woord. Enkele kanttekeningen bij ontbinding zonder vereffening, TOP 2014/171. Omdat turboliquidatie de gangbare term is voor ontbinding via art. 2:19 lid $4 \mathrm{BW}$, gebruik ik het begrip turboliquidatie.

2. Zie bijv. S. Renssen, De turboliquidatie van de besloten vennootschap (diss. Maastricht), Deventer: Wolters Kluwer 2016, p. 169; M.Y. Nethe, Turboliquidatie: oorbaar gebruik, abusievelijk gebruik en misbruik, in: B. Bier, M. van Olffen \& B. Snijder-Kuipers (red.), Handboek notarieel ondernemingsrecht, B.V. en N.V. (Serie vanwege het Van der Heijden Instituut), Deventer: Wolters Kluwer 2016, p. 405-493; M.A.L.M. Willems, De toetsing ex nunc als zwaard van Damocles voor bestuurders, TvCu 2015, afl. 5-6, p. 201-203; HR 18 december 2015, ECLI:NL:HR:2015:3636; Hof Arnhem-Leeuwarden 1 februari 2016, ECLI:NL:GHARL:2016:593.

3. HR 27 januari 1995, ECLI:NL:HR:1995:ZC1631, NJ 1995/579 (APH/Söderqvist q.q.), r.o. 4.3.
De vraag die in deze bijdrage aan de orde komt, is of een vordering op grond van artikel 2:248 BW, een Peeters/Gatzenvordering en een paulianavordering baten van de rechtspersoon zijn in de zin van artikel 2:19 lid $4 \mathrm{BW}$. Ten aanzien van de artikel 2:248 BW-vordering wordt deze vraag in de rechtspraak verschillend beantwoord. Volgens het Gerechtshof Amsterdam ${ }^{4}$ is een artikel 2:248 BW-vordering geen bate van de rechtspersoon zoals bedoeld in artikel 2:19 lid $4 \mathrm{BW}$, terwijl dit volgens het Gerechtshof Den Haag 5 en veel lagere rechtspraak $^{6}$ wel het geval is. Dit brengt rechtsonzekerheid met zich mee voor schuldeisers die bij een faillissementsaanvraag stellen dat de turbogeliquideerde rechtspersoon niet is opgehouden te bestaan omdat de curator in faillissement een vordering in kan stellen op grond van artikel 2:248 BW.

Omdat de artikel 2:248 BW-vordering naar het oordeel van het Gerechtshof Amsterdam geen bate is van de rechtspersoon in de zin van artikel 2:19 lid $4 \mathrm{BW}$, kunnen bestuurders in dat ressort door turboliquidatie toe te passen voorkomen dat het faillissement van de vennootschap wordt uitgesproken. Zodoende kunnen zij voorkomen dat een curator wordt aangesteld die een beroep kan doen op artikel 2:248 BW. De mogelijkheid bestaat dat andere hoven meegaan met de lijn die het Gerechtshof Amsterdam uitgezet heeft. Zowel de rechtsongelijkheid als de mogelijkheid tot misbruik is mijns inziens ongewenst. Hetzelfde is aan de orde als een Peeters/Gatzenvordering of een paulianavordering niet gezien wordt als bate van de rechtspersoon zoals bedoeld in artikel 2:19 lid 4 BW. Daarom wordt besproken welke alternatieven schuldeisers hebben voor een faillissementsaanvraag. Omdat artikel 2:19 lid $4 \mathrm{BW}$ aanleiding geeft tot met elkaar strijdige rechtspraak en daarmee tot rechtsongelijkheid, wordt tot slot een aanbeve-

4. Hof Amsterdam 31 maart 2011, ECLI:NL:GHAMS:2011:BQ1156, JOR 2011/307, r.o. 3.9 .

5. Hof Den Haag 6 september 2012, ECLI:NL:GHSGR:2012:BX7085, JOR 2013/217 m.nt. M.Y. Nethe; Hof Den Haag 2 juli 2015, ECLI:NL:GHDHA:2015:1846, JOR 2016/47 m.nt. S. Renssen.

6. Zie o.a. Rb. Arnhem 11 januari 2006, ECLI:NL:RBARN:2006: AV0473, JOR 2006/120; Rb. Arnhem 26 juli 2006, ECLI:NL: RBARN:2006:AZ8913, JOR 2007/29; Rb. Midden-Nederland 9 december 2013, ECLI:NL:RBMNE:2013:7202; Rb. Overijssel 12 maart 2014, ECLI:NL:RBOVE:2014:1519; Rb. Den Haag 24 februari 2015, ECLI:NL:RBDHA:2015:1970. 


\section{Maandblad}

Ondernemingsrecht

ling gedaan aan de wetgever tot aanpassing van artikel 2:19 lid $4 \mathrm{BW}$.

\section{Baten in de zin van artikel 2:19 lid 4 BW}

In deze paragraaf wordt onderzocht wat verstaan wordt onder baten van de rechtspersoon in de zin van artikel 2:19 lid 4 BW. Artikel 2:19 lid 4 BW luidt:

'Indien de rechtspersoon op het tijdstip van zijn ontbinding geen baten meer heeft, houdt hij alsdan op te bestaan. In dat geval doet het bestuur of, bij toepassing van artikel 19a, de Kamer van Koophandel, daarvan opgaaf aan de registers waar de rechtspersoon is ingeschreven.'

De Hoge Raad heeft in een aantal arresten geoordeeld dat niet te veel eisen moeten worden gesteld aan het bestaan van een bate als bedoeld in artikel 2:19 lid 4 BW. Reeds in 1991 oordeelde de Hoge Raad dat de rechter met terughoudendheid moet toetsen of het bestaan van een gestelde bate voldoende aannemelijk is. Een gepretendeerd - maar betwist en niet in rechte vastgesteld - vorderingsrecht wordt gelijkgesteld met een bate in de zin van artikel 2:19 lid $4 \mathrm{BW}$. $^{7}$ In het arrest APH/Söderqvist q.q. oordeelde de Hoge Raad dat slechts 'summierlijk [moet blijken] van feiten of omstandigheden die voldoende aannemelijk maken dat er nog baten zijn'.

Uit het voorgaande blijkt ten eerste dat de Hoge Raad het begrip baten in de zin van artikel 2:19 lid $4 \mathrm{BW}$ ruim uitlegt. Ook een gepretendeerd vorderingsrecht wordt onder het begrip baten geschaard, terwijl het mogelijk is dat nadien in rechte vastgesteld wordt dat het gepretendeerde vorderingsrecht niet bestaat. In de tweede plaats is de Hoge Raad van oordeel dat een verlichte bewijslast geldt met betrekking tot het bestaan van een bate.

Hoewel de Hoge Raad het begrip baten in de zin van artikel 2:19 lid 4 BW ruim uitlegt, bestaat onduidelijkheid over de vraag of ook vorderingen van anderen dan de rechtspersoon, in het bijzonder de curator of de boedel, geschaard kunnen worden onder artikel 2:19 lid $4 \mathrm{BW}$. Uit de eerste volzin van artikel 2:19 lid 4 BW blijkt immers dat een rechtspersoon ophoudt te bestaan als de rechtspersoon geen baten meer heeft. Het is daarom duidelijk dat de rechtspersoon voortbestaat als hijzelf nog baten heeft, bijvoorbeeld uit hoofde van artikel 2:9 BW. De vraag is of de rechtspersoon ook voortbestaat als derden, waaronder de gezamenlijke schuldeisers, een bate hebben.

Hierna wordt onderzocht of de vordering op grond van artikel 2:248 BW, de Peeters/Gatzen-vordering en de paulianavordering baten zijn van de rechtspersoon. Allereerst ga ik in op de

7. HR 11 oktober 1991, ECLI:NL:HR:1991:ZC0366, NJ 1992/132 (Bouwbedrijf Vianen), r.o. 3.3.

8. HR 27 januari 1995, ECLI:NL:HR:1995:ZC1631, NJ 1995/579 (APH/Söderqvist q.q.), r.o. 4.3; zie ook HR 26 maart 2004, ECLI:NL:PHR:2004:AO2779, JOR 2004/127 (Zohar Food International), concl. A-G Timmerman, par. 2.3. vraag of sprake is van vorderingen van de rechtspersoon. Voor zover dat niet het geval blijkt te zijn, behandel ik de vervolgens relevante vraag of deze vorderingen niettemin geschaard kunnen worden onder het begrip baten zoals bedoeld in artikel 2:19 lid 4 BW.

\section{Artikel 2:248 BW als vordering van de curator namens gezamenlijke crediteuren}

Voordat de vraag kan worden beantwoord of de vordering van artikel 2:248 BW een bate is in de zin van artikel 2:19 lid 4 $\mathrm{BW}$, wordt onderzocht of de artikel 2:248 BW-vordering een vordering van de rechtspersoon of van de schuldeisers is.

Op grond van artikel 2:248 lid 1 BW kan een curator in geval van faillissement iedere bestuurder van een BV aansprakelijk stellen indien het bestuur zijn taak kennelijk onbehoorlijk heeft vervuld en aannemelijk is dat dit een belangrijke oorzaak is van het faillissement. ${ }^{9}$ Lid 2 van artikel 2:248 BW geeft aan dat vaststaat dat het bestuur zijn taak kennelijk onbehoorlijk heeft vervuld indien een van de twee kernverplichtingen niet in acht is genomen. Deze kernverplichtingen zijn het voeren van een deugdelijke administratie (art. 2:10 BW) en het tijdig publiceren van de jaarstukken (art. 2:394 BW).

\section{Vordering namens gezamenlijke schuldeisers}

Langere tijd is niet geheel duidelijk geweest of een vordering op grond van artikel 2:248 BW een vordering van de curator is ten behoeve van de gezamenlijke schuldeisers of ten behoeve van de failliete vennootschap. In de memorie van toelichting bij de wijziging van artikel 2:248 BW staat:

'De vordering van de curator ex artikel 138 of 248 Boek 2 $\mathrm{BW}$ is een vordering ten behoeve van de schuldeisers van de vennootschap. ${ }^{10}$

In de memorie van antwoord aan de Eerste Kamer was de minister minder stellig. Hij stelde dat een bestuurder die aangesproken wordt op grond van artikel 2:248 BW 'in de visie van Van Schilfgaarde' een schuldenaar is van de gezamenlijke schuldeisers en niet van de vennootschap. De minister gaf aan dat hij geneigd is "s hoogleraars uitgangspunt te onderschrijven'. Hij constateerde wel dat hierover door Van der Grinten anders gedacht wordt en nam (omdat het 'voor een bewindsman hachelijk [is] zich onder professoren te begeven') geen definitief standpunt in. ${ }^{11}$ Van der Grinten bleef bij het bewerken van het Handboek in 1992 bij zijn standpunt dat het de curator als vertegenwoordiger van de vennootschap is die een vordering ex artikel 2:248 BW instelt. ${ }^{12}$

9. Gemakshalve wordt in dit artikel uitgegaan van de BV. Voor de NV geldt hetzelfde in het kader van art. 2:138 BW.

10. Kamerstukken II 1980/81, 16631, 3, p. 6.

11. Kamerstukken I 1985/86, 16631, 27b, p. 7.

12. Van der Heijden/Van der Grinten, Handboek voor de naamloze en de besloten vennootschap, Zwolle: W.E.J. Tjeenk Willink 1992, nr. 399.1. Zie ook W.C.L. van der Grinten, De nieuwe misbruikwetgeving, De Naamlooze Vennootschap 1986, afl. 1, p. 19-23. 
De Hoge Raad oordeelde reeds in 1990 dat een vordering op grond van artikel 2:248 BW een vordering is ten behoeve van de gezamenlijke schuldeisers. ${ }^{13}$ Mede om die reden kan de curator een vordering ex artikel 2:248 BW niet cederen. In 2009 herhaalde de Hoge Raad zijn oordeel:

'De aansprakelijkheid van bestuurders ingevolge de art. 2:138 en 2:248 BW is geen aansprakelijkheid jegens de gefailleerde vennootschap maar een aansprakelijkheid jegens de boedel.' ${ }^{14}$

Een bestuurder kan een vordering op de rechtspersoon daarom niet verrekenen met een door de curator ingestelde vordering ex artikel 2:248 BW. Ook kan een bestuurder een vordering op grond van artikel 2:248 BW niet pareren met een beroep op decharge. ${ }^{15}$ Decharge is immers verleend door de rechtspersoon en de rechtspersoon kan een bestuurder niet namens derden ontslaan uit zijn aansprakelijkheid.

In de door Dortmond herziene versie van het Handboek wordt geconcludeerd dat het standpunt in de druk uit 1992 na het genoemde arrest van de Hoge Raad achterhaald is. ${ }^{16} \mathrm{De}$ heersende leer is dat een vordering ex artikel 2:248 BW een vordering van de curator is ten behoeve van de gezamenlijke crediteuren en niet ten behoeve van de vennootschap. ${ }^{17}$

\section{Vordering ex artikel 2:248 BW als bate van de rechtspersoon}

In de literatuur wordt de vraag of een vordering op grond van artikel 2:248 BW gezien kan worden als een bate van de rechtspersoon in de zin van artikel 2:19 lid $4 \mathrm{BW}$ veelal positief beantwoord. Renssen stelt dat een vordering ex artikel 2:248 BW met het oog op de proceseconomie en derdenbescherming moet gelden als een vordering van de rechtspersoon, omdat een bestuurder anders kan wegkomen met onbehoorlijk bestuur en een ten onrechte genomen besluit tot turboliquidatie. ${ }^{18}$ Ook Nethe ${ }^{19}$ en Kroeze ${ }^{20}$ zijn van mening dat een vordering op grond van artikel 2:248 BW valt onder het begrip baten in de zin van artikel 2:19 lid 4 BW. Oppedijk van

13. HR 7 september 1990, ECLI:NL:HR:1990:AB9949, NJ 1991/52 m.nt. J.M.M. Maeijer, r.o. 3.2.

14. HR 18 september 2009, ECLI:NL:HR:2009:BI5912, JOR 2010/29 m.nt. S.C.J.J. Kortmann en N.E.D. Faber, r.o. 3.4.

15. B.F. Assink \& W.J. Slagter, Compendium ondernemingsrecht (deel 1), Deventer: Kluwer 2013, par. 51.14

16. Van der Heijden/Van der Grinten/Dortmond, Handboek voor de naamloze en de besloten vennootschap, Deventer: Kluwer 2013, nr. 399.1 .

17. Zie ook Assink \& Slagter 2013, par. 51.14 (p. 1062); Van Schilfgaarde/ Winter \& Wezeman, Van de BV en de NV, Deventer: Kluwer 2013, nr. 48; N.J. Polak \& M. Pannevis, Insolventierecht, Deventer: Kluwer 2014, par. 5.3.3; Asser/Maeijer, Van Solinge \& Nieuwe Weme 2-II* $2009 / 455$.

18. Renssen 2016, p. 169; S. Renssen, Het faillissement van een herleefde turbo-geliquideerde BV: een vreemde eend in de bijt, TvOB 2013, afl. 4 , p. 121-126 en Hof Den Haag 2 juli 2015, ECLI:NL:GHDHA: 2015:1846, JOR 2016/47 m.nt. S. Renssen.

19. Nethe 2016, p. 411 en 412.

20. Asser/Maeijer \& Kroeze 2-I* 2015/403.
Veen $^{21}$ en Willems ${ }^{22}$ zijn van mening dat de artikel 2:248 BW-vordering hier niet onder valt, onder meer omdat uit de tekst van artikel 2:19 lid 4 BW duidelijk blijkt dat de rechtspersoon een bate moet hebben, terwijl een vordering op grond van artikel 2:248 BW wordt ingesteld door de curator ten behoeve van de gezamenlijke schuldeisers.

De Hoge Raad heeft zich tot op heden niet gebogen over de vraag of een vordering ex artikel 2:248 BW gekwalificeerd kan worden als een bate van de rechtspersoon in de zin van artikel 2:19 lid 4 BW. A-G Huydecoper heeft in een conclusie wel enige overwegingen gewijd aan de discussie. ${ }^{23}$ Als inleiding op de bespreking van de cassatiemiddelen merkte de A-G op dat het begrip baten 'ruim mag worden uitgelegd'. A-G Huydecoper stelt zich op het standpunt dat een vordering op grond van artikel 2:248 $\mathrm{BW}$ en een Peeters/Gatzen-vordering gezien kunnen worden als een bate van de rechtspersoon in de zin van artikel 2:19 lid $4 \mathrm{BW}$. Daaraan staat niet in de weg dat dergelijke vorderingen 'naar gangbare boekhoudkundige maatstaven geen baten van de vennootschap zouden mogen worden genoemd'. ${ }^{24}$ Als argumenten voor zijn standpunt voert de A-G aan dat het bestuur, dat opgeeft bij het handelsregister dat de rechtspersoon geen baten meer heeft, conflicterende belangen heeft en niet dezelfde middelen heeft als een curator in faillissement. ${ }^{25}$ Bestuurders hebben - mede daarom - de mogelijkheid zichzelf te bevoordelen en/of crediteuren te benadelen door gebruik te maken van turboliquidatie. ${ }^{26}$

In de lagere rechtspraak wordt veelal aangenomen dat een vordering ex artikel 2:248 BW gezien kan worden als een bate van de rechtspersoon zoals bedoeld in artikel 2:19 lid 4 BW. ${ }^{27} \mathrm{Het}$ Gerechtshof Den Haag motiveert dit oordeel in het arrest van 2 juli 2015 :

'De aan de curator in het faillissement toekomende vordering op grond van artikel 2:248 BW is weliswaar strikt genomen geen bate van de vennootschap, maar een bate voor de boedel (de gezamenlijke crediteuren), maar het begrip bate dient ruim te worden uitgelegd. ${ }^{28}$

21. E.J. Oppedijk van Veen, Turbo-liquidatie en bestuurdersaansprakelijkheid, V\&O 2006, afl. 4, p. 71-74.

22. Willems 2015.

23. HR 20 juni 2008, ECLI:NL:PHR:2008:BD1857, concl. A-G Huydecoper.

24. HR 20 juni 2008, ECLI:NL:PHR:2008:BD1857, concl. A-G Huydecoper, par. 13.

25. HR 20 juni 2008, ECLI:NL:PHR:2008:BD1857, concl. A-G Huydecoper, par. 11.

26. HR 20 juni 2008, ECLI:NL:PHR:2008:BD1857, concl. A-G Huydecoper, par. 12.

27. Zie o.a. Rb. Arnhem 11 januari 2006, ECLI:NL:RBARN 2006:AV0473, JOR 2006/120; Rb. Arnhem 26 juli 2006, ECLI:NL:RBARN:2006:AZ8913, JOR 2007/29; Hof Den Haag 6 september 2012, ECLI:NL:GHSGR:2012:BX7085, JOR 2013/217 m.nt. M.Y. Nethe; Rb. Midden-Nederland 9 december 2013, ECLI:NL:RBMNE:2013:7202; Rb. Overijssel 12 maart 2014, ECLI:NL:RBOVE:2014:1519; Rb. Den Haag 24 februari 2015, ECLI:NL:RBDHA:2015:1970.

28. Hof Den Haag 2 juli 2015, ECLI:NL:GHDHA:2015:1846, JOR 2016/47 m.nt. S. Renssen. 


\section{Maandblad}

Ondernemingsrecht

Het Gerechtshof Amsterdam vaart een andere koers en heeft zich ertegen verzet om een vordering op grond van artikel 2:248 BW te zien als een bate van de rechtspersoon:

'[A] angenomen [moet worden] dat een vordering uit hoofde van bestuurdersaansprakelijkheid op grond van artikel 2:248 BW is aan te merken als een vordering van de curator ten behoeve van de gezamenlijke crediteuren, die alleen daarom al geen bate voor de rechtspersoon oplevert (wel voor de boedel). ${ }^{29}$

Omdat zowel in de literatuur als in de rechtspraak discussie is over de vraag of een vordering op grond van artikel 2:248 BW valt onder het begrip baten zoals bedoeld is in artikel 2:19 lid $4 \mathrm{BW}$, is het in het kader van de rechtszekerheid van belang dat de Hoge Raad zich hierover uitlaat. Het is in het belang van de schuldeisers van de rechtspersoon, en mijns inziens daarom wenselijk, als een artikel 2:248 BW-vordering gezien wordt als een bate in de zin van artikel 2:19 lid $4 \mathrm{BW}$. Als schuldeisers aannemelijk kunnen maken dat de curator in faillissement een dergelijke vordering in kan stellen en deze vordering slaagt, dan komt er geld beschikbaar voor de gezamenlijke schuldeisers. In dat geval is een faillissement zinvol, omdat de curator dan iets te verdelen heeft onder de gemeenschappelijke schuldeisers. Dogmatisch gezien kleven hier wel bezwaren aan.

Uit artikel 2:19 lid 4 BW blijkt duidelijk dat een rechtspersoon ophoudt te bestaan als 'de rechtspersoon op het tijdstip van zijn ontbinding geen baten meer heeft'. Op twee manieren zou kunnen worden beargumenteerd dat een vordering op grond van artikel 2:248 BW hieronder valt. In de eerste plaats kan worden gesteld dat artikel 2:19 lid $4 \mathrm{BW}$ niet beperkt is tot baten van de rechtspersoon. In de tweede plaats kan worden gesteld dat artikel 2:248 BW wel een bate van de rechtspersoon is. Naar mijn mening brengen beide argumenten bezwaren met zich mee.

De stelling dat artikel 2:19 lid $4 \mathrm{BW}$ niet beperkt is tot baten van de rechtspersoon, vindt geen steun in de wetsgeschiedenis. In de wetsgeschiedenis wordt nauwelijks ingegaan op het begrip baten van de rechtspersoon. Wel staat in de memorie van toelichting dat er nog een bate is 'indien de rechtspersoon bijvoorbeeld nog een vordering heeft tegen bestuurders of commissarissen wegens wanbeleid'. ${ }^{30}$ Omdat de memorie van toelichting spreekt over een vordering van de rechtspersoon, wordt kennelijk een vordering op grond van artikel 2:9 BW bedoeld en niet een vordering op grond van artikel 2:248 BW. De wetsgeschiedenis geeft dus geen handvatten aan de rechter om te bepalen of artikel 2:19 lid $4 \mathrm{BW}$ al dan niet beperkt is tot baten van de rechtspersoon. Het is in beginsel aan de wetgever en niet aan de rechter om duidelijk te maken of onder

29. Hof Amsterdam 31 maart 2011, ECLI:NL:GHAMS:2011:BQ1156, JOR 2011/307, r.o. 3.9.

30. Kamerstukken II 1982/83, 17725,3 , p. 69. artikel 2:19 lid 4 BW ook baten van anderen dan de rechtspersoon geschaard worden.

De stelling dat artikel 2:248 BW een bate van de rechtspersoon is, brengt een ander probleem met zich mee. In 2009 heeft de Hoge Raad geoordeeld dat de op grond van artikel 2:248 BW aansprakelijk zijnde bestuurder geen schuldenaar is van de failliete rechtspersoon. De bestuurder kan zijn schuld aan de gezamenlijke schuldeisers niet verrekenen met een vordering op de failliete rechtspersoon. ${ }^{31}$ Door een vordering ex artikel 2:248 BW te zien als bate van de rechtspersoon in de zin van artikel 2:19 lid $4 \mathrm{BW}$ valt de motivering weg waarom een bestuurder een dergelijke schuld niet kan verrekenen met een vordering op de rechtspersoon.

Hoewel het mijns inziens wenselijk is als de Hoge Raad zou oordelen dat een vordering op grond van artikel 2:248 BW gezien moet worden als een bate in de zin van artikel 2:19 lid 4 $\mathrm{BW}$, zou een dergelijk oordeel naar mijn mening, gelet op het voorgaande, dogmatisch bezwaarlijk zijn.

\section{Peeters/Gatzen-vordering}

In het Peeters/Gatzen-arrest heeft de Hoge Raad geoordeeld dat de curator bevoegd is voor de belangen van de gezamenlijke schuldeisers op te komen door het instellen van een vordering uit onrechtmatige daad tegen een derde die betrokken is bij benadeling van schuldeisers. ${ }^{32}$ De Peeters/Gatzen-vordering kan niet worden ingesteld door de failliet zelf, maar uitsluitend door de curator in faillissement. De opbrengst van de Peeters/Gatzen-vordering valt in de boedel en komt ten goede aan de gezamenlijke schuldeisers. ${ }^{33}$ Reeds in het Peeters/ Gatzen-arrest heeft de Hoge Raad geoordeeld dat de wederpartij van de curator geen schuldenaar is van de failliet. Om deze reden kan een Peeters/Gatzen-vordering niet worden verrekend met een vordering op de failliet. ${ }^{34}$

In de literatuur en rechtspraak wordt nauwelijks aandacht besteed aan de vraag of een Peeters/Gatzen-vordering moet worden gezien als een bate van de rechtspersoon in de zin van artikel 2:19 lid 4 BW. Uitsluitend A-G Huydecoper heeft zich hierover uitgelaten en het standpunt ingenomen dat de Peeters/Gatzen-vordering als zodanig gezien moet worden. ${ }^{35}$

Net als de artikel 2:248 BW-vordering is de Peeters/Gatzenvordering geen vordering van de rechtspersoon, maar een vordering van de gezamenlijke schuldeisers. Net als de vordering op grond van artikel 2:248 BW kan de Peeters/Gatzen-vorde-

31. HR 18 september 2009, ECLI:NL:HR:2009:BI5912, JOR 2010/29 m.nt. S.C.J.J. Kortmann en N.E.D. Faber, r.o. 3.4.

32. HR 14 januari 1983, ECLI:NL:HR:1983:AG4521, NJ 1983/597 (Peeters q.q./Gatzen), r.o. 3.3.

33. HR 16 september 2005, ECLI:NL:HR:2005:AT7797, NJ 2006/52 (De Bont/Bannenberg q.q.), r.o. 3.5.

34. HR 14 januari 1983, ECLI:NL:HR:1983:AG4521, NJ 1983/597 (Peeters q.q./Gatzen), r.o. 3.4.

35. HR 20 juni 2008, ECLI:NL:PHR:2008:BD1857, concl. A-G Huydecoper, par. 13. 
ring niet worden verrekend met een vordering op de failliet. Het is daarom ook ten aanzien van de Peeters/Gatzen-vordering dogmatisch bezwaarlijk om deze vordering te zien als bate van de rechtspersoon in de zin van artikel 2:19 lid $4 \mathrm{BW}$.

\section{Pauliana als bate van de rechtspersoon}

Schuldeisers die het faillissement van een turbogeliquideerde rechtspersoon aanvragen, stellen zich in sommige gevallen op het standpunt dat de rechtspersoon niet is opgehouden te bestaan omdat een beroep gedaan kan worden op pauliana. Het is daarom niet alleen ten aanzien van de vordering op grond van artikel 2:248 BW van belang om vast te stellen of sprake is van een vordering van de rechtspersoon in de zin van artikel 2:19 lid 4 BW, maar ook ten aanzien van de paulianavordering. Als de paulianavordering geen vordering van de rechtspersoon is, bestaat immers het risico dat ook deze vordering reeds daarom niet beschouwd wordt als bate van de rechtspersoon in de zin van artikel 2:19 lid 4 BW. Dit zou rechtsonzekerheid en rechtsongelijkheid met zich kunnen meebrengen. Het Gerechtshof Arnhem-Leeuwarden heeft geoordeeld dat een mogelijk paulianeuze rechtshandeling die voor vernietiging in aanmerking komt, een bate met zich meebrengt in de zin van artikel 2:19 lid $4 \mathrm{BW} .{ }^{36}$ De faillissementspauliana en de schuldeiserspauliana worden hierna afzonderlijk behandeld.

\subsection{Faillissementspauliana}

Uit artikel 42 van de Faillissementswet ( $\mathrm{Fw}$ ) blijkt dat uitsluitend de curator een rechtshandeling kan vernietigen wegens faillissementspauliana ten behoeve van de boedel. ${ }^{37}$ De schuldenaar zelf en schuldeisers kunnen een rechtshandeling niet (laten) vernietigen op grond van artikel 42 e.v. Fw. Een vordering op grond van artikel 42 e.v. Fw is daarom geen vordering van de rechtspersoon.

Vernietiging op grond van artikel 42 e.v. Fw heeft terugwerkende kracht. ${ }^{38}$ Als een goed verkocht is door een paulianeuze rechtshandeling, is het gevolg hiervan dat het goed nimmer het vermogen van de schuldenaar heeft verlaten. ${ }^{39}$ De schuldenaar is daarom - met terugwerkende kracht - eigenaar van het goed gebleven en heeft daarom wel een bate nádat een rechtshandeling is vernietigd wegens faillissementspauliana. Op het moment van de faillissementsaanvraag kan de rechtshandeling nog niet zijn vernietigd wegens faillissementspauliana en bestaat er strikt genomen nog geen bate van de rechtspersoon.

36. Hof Arnhem-Leeuwarden 1 februari 2016, ECLI:NL:GHARL: 2016:593, r.o. 3.6.

37. Zie ook B. Wessels, Insolventierecht III. Gevolgen van faillietverklaring (2), Deventer: Kluwer 2013, nr. 3129-3130 en HR 23 maart 2001, ECLI:NL:HR:2001:AG3894, JOR 2001/116, r.o. 3.11. Zie ook art. 49 lid $1 \mathrm{Fw}$.

38. Polak \& Pannevis 2014, par. 5.3.3; contractsoverneming: HR 24 april 2009, ECLI:NL:HR:2009:BF3917, NJ 2009/416 (Dekker q.q./Lutèce), r.o. 3.2.4 en 3.2.5

39. Vgl. in het kader van contractsoverneming HR 24 april 2009, ECLI:NL:HR:2009:BF3917, NJ 2009/416 (Dekker q.q./Lutèce), r.o. 3.2.4 en 3.2.5.
Van het zakelijke eigendomsrecht moet het persoonlijke recht tot teruggave worden onderscheiden. ${ }^{40}$ Uit artikel 51 lid $1 \mathrm{Fw}$ volgt dat, na vernietiging van een rechtshandeling door de curator, een verbintenis tot teruggave bestaat jegens de curator q.q. en niet jegens de schuldenaar. ${ }^{41}$ De verbintenis tot teruggave is daarom geen bate van de rechtspersoon.

Uit het voorgaande volgt dat de mogelijkheid tot vernietiging van een rechtshandeling op grond van artikel $42-48 \mathrm{Fw}$ en ook de ongedaanmakingsverplichting op grond van artikel $51 \mathrm{Fw}$ geen baten van de rechtspersoon zijn.

\subsection{Schuldeiserspauliana}

Een beroep op pauliana op grond van het BW staat uitsluitend open voor schuldeisers die in hun verhaalsmogelijkheden zijn benadeeld. ${ }^{42}$ De rechtspersoon die partij is bij de rechtshandeling kan geen beroep doen op pauliana. Een dergelijke rechtsvordering komt daarom niet toe aan de rechtspersoon. Uiteraard geldt hetzelfde voor de vernietiging door middel van een buitengerechtelijke verklaring. Dat ligt mijns inziens anders nadat de rechtshandeling is vernietigd met een beroep op artikel 3:45 e.v. BW. Als een koopovereenkomst wegens pauliana wordt vernietigd, keert het verkochte goed terug in het vermogen van de verkoper. ${ }^{43}$ Omdat de rechtshandeling met terugwerkende kracht is vernietigd, ${ }^{44}$ is de verkoper nog steeds eigenaar van het verkochte goed. Door de vernietiging ontstaat niet alleen een 'herleefd' zakelijk recht, maar ook een verbintenis tot teruggave wegens onverschuldigde betaling. ${ }^{45}$ De rechtshandeling op grond waarvan gepresteerd is, bestaat immers niet meer.

De eigendom van het goed dat terugkeert in het vermogen van de rechtspersoon die een paulianeuze rechtshandeling heeft verricht, is een bate van de rechtspersoon. Ook de verbintenis tot teruggave die ontstaat wegens een succesvol beroep op pauliana is een bate van de rechtspersoon. ${ }^{46}$ De paulianavordering is daarom geen bate van de rechtspersoon, maar het herleefde eigendomsrecht en de verbintenis tot teruggave na een succesvolle vernietiging zijn wel baten van de rechtspersoon.

\section{Alternatieven}

Zoals uit het voorgaande blijkt, zijn de vordering ex artikel 2:248 BW en de Peeters/Gatzen-vordering geen baten van de rechtspersoon. De paulianavordering op zichzelf is ook geen bate van de rechtspersoon, maar door vernietiging van een paulianeuze rechtshandeling ontstaat er wel een bate van de

40. Vgl. Asser/Hartkamp \& Sieburgh 6-IV 2015/442.

41. Wessels 2013, nr. 3245-3246.

42. Art. 3:45 lid 1 BW; Asser/Hartkamp \& Sieburgh 6-III 2014/586.

43. Jac. Hijma e.a., Rechtshandeling en overeenkomst (Studiereeks Burgerlijke Recht 3), Deventer: Kluwer 2013, nr. 208; T.J. Mellema-Kranenburg, GS Vermogensrecht, art. 3:45 BW, aant. 91 (online, laatst bijgewerkt op 7 juli 2015).

44. Art. 3:53 BW.

45. G. van Dijck, Pauliana (Monografieën BW, deel B4), Deventer: Kluwer 2008, p. 49.

46. Zie ook M. van der Vlugt, Turbo-liquidatie, V\&O 1997, afl. 7-8, p. 83 en 84 . 


\section{Maandblad}

Ondernemingsrecht

rechtspersoon. Ten aanzien van de artikel 2:248 BW-vordering heeft het Gerechtshof Amsterdam geoordeeld dat dit geen bate is van de rechtspersoon en daarom niet valt onder het begrip baten zoals bedoeld in artikel 2:19 lid 4 BW. Ook een paulianavordering op grond van de $\mathrm{Fw}$ is op zichzelf geen bate van de rechtspersoon. Onder meer het Gerechtshof Amsterdam zou om deze reden kunnen oordelen dat deze vordering, net als de artikel 2:248 BW-vordering, geen bate van de rechtspersoon is in de zin van artikel 2:19 lid 4 BW. Als de turbogeliquideerde rechtspersoon geen (andere) baten heeft, kan het faillissement dan niet worden uitgesproken. Deze conclusie brengt onwenselijke gevolgen met zich als er voor schuldeisers geen alternatieven bestaan om bestuurders en derden aansprakelijk te stellen of een rechtshandeling te vernietigen op grond van de BW-pauliana. Bestuurders zouden dan misbruik kunnen maken van turboliquidatie ten koste van de schuldeisers. In deze paragraaf schets ik daarom alternatieven voor schuldeisers.

\subsection{Aansprakelijkheid op grond van artikel 6:162 en 2:9 BW}

Als een rechtspersoon is turbogeliquideerd, kan een crediteur van de rechtspersoon de bestuurder aansprakelijk stellen op grond van artikel 6:162 BW. Een vordering van een individuele schuldeiser op grond van artikel 6:162 BW is immers geen vordering die ingesteld moet worden in het faillissement van de rechtspersoon jegens de bestuurder. Turboliquidatie heeft daarom geen invloed op de externe aansprakelijkheid van de bestuurder jegens een individuele crediteur. Turboliquidatie heeft ook geen invloed op de aansprakelijkheid van derden wegens benadeling van een individuele schuldeiser. Ook als de curator in faillissement een Peeters/Gatzen-vordering heeft ingesteld, kan een individuele schuldeiser de derde op basis van hetzelfde feitencomplex aansprakelijk stellen op grond van onrechtmatige daad. ${ }^{47}$ Als alternatief voor de Peeters/Gatzenvordering kan een individuele schuldeiser derden derhalve aansprakelijk stellen op grond van artikel 6:162 BW wegens benadeling van hem als schuldeiser. Een nadeel van een individuele actie op grond van artikel 6:162 BW ten opzichte van de Peeters/Gatzen-vordering is dat de derde gebruik kan maken van alle verweren die hij kan inroepen tegenover de individuele schuldeiser, terwijl dat niet mogelijk is bij de Peeters/ Gatzen-vordering. ${ }^{48}$

Daarnaast is een vordering op grond van artikel 2:9 BW wél een vordering van de rechtspersoon op de bestuurder. Uit de wetsgeschiedenis volgt daarom ook dat een vordering op grond van artikel 2:9 BW gezien moet worden als een bate van de rechtspersoon in de zin van artikel 2:19 lid 4 BW. ${ }^{49}$ Een schuldeiser kan daarom in ieder geval het faillissement aanvragen als de rechtspersoon een vordering op grond van artikel

47. HR 21 december 2001, ECLI:NL:HR:2001:AD2684, 3.4.4 en 3.4.5, NJ 2005/95 (Lunderstädt/De Kok c.s.).

48. HR 23 december 1994, ECLI:NL:HR:1994:ZC1590, NJ 1996/628 (Notarissen THB II), r.o. 4.3.2.

49. Kamerstukken II 1982/83, 17725, 3, p. 69.
2:9 BW in kan stellen tegen een bestuurder. De schuldeiser zal daarvoor aannemelijk moeten maken dat een bestuurder zijn taak onbehoorlijk vervuld heeft en dat hem hiervoor een ernstig verwijt gemaakt kan worden. Aangezien volgens de Hoge Raad slechts summierlijk moet blijken van feiten en omstandigheden die het bestaan van een bate aannemelijk maken, ${ }^{50}$ is de bewijslast voor een crediteur beperkt. Een bestuurder van een turbogeliquideerde rechtspersoon kan daarom niet in alle gevallen wegkomen met onbehoorlijk bestuur als een vordering ex artikel 2:248 BW niet gezien wordt als bate van de rechtspersoon in de zin van artikel 2:19 lid $4 \mathrm{BW} .{ }^{51}$ Als de bestuurder onbehoorlijk bestuur in de zin van artikel 2:9 BW verweten kan worden, moet de rechtbank alsnog het faillissement van de rechtspersoon uitspreken als aan de voorwaarden voor het uitspreken van een faillissement is voldaan.

Een nadeel van het aannemelijk moeten maken van een vordering op grond van artikel 2:9 BW ten opzichte van artikel 2:248 BW is dat artikel 2:9 BW geen bewijsvermoedens kent voor onbehoorlijk bestuur. Artikel 2:248 lid 2 BW zorgt ervoor dat onbehoorlijk bestuur vaststaat als het bestuur niet heeft voldaan aan de boekhoudplicht of de plicht om de jaarstukken tijdig te deponeren. Volgens de memorie van toelichting is de reden hiervan tweeledig. In de eerste plaats is het voor een curator erg lastig om bewijs te leveren van onbehoorlijk bestuur bij het ontbreken van een deugdelijke boekhouding of een jaarrekening. In de tweede plaats duidt het ontbreken van een deugdelijke boekhouding of te laat (of in het geheel niet) gepubliceerde jaarstukken op 'een weinig betrouwbaar en serieus ondernemerschap. ${ }^{52}$ Hoewel de aansprakelijkheidsnormen van artikel 2:9 en 2:248 BW van elkaar verschillen, kan een rechter het niet voldoen aan de boekhoudplicht (of publicatieplicht) mijns inziens als bijkomende omstandigheid meewegen in zijn oordeel dat summierlijk blijkt van het bestaan van onbehoorlijk bestuur in de zin van artikel 2:9 BW. Een bestuurder die zijn administratie niet op orde heeft en de jaarstukken niet (tijdig) heeft gepubliceerd, neemt zijn taak immers kennelijk niet serieus.

Een tweede nadeel van een vordering ex artikel 2:9 BW is dat een bestuurder, nadat hem geldig decharge is verleend, niet meer aansprakelijk gesteld kan worden door de rechtspersoon. ${ }^{53}$ Hierdoor vervalt de mogelijkheid voor een schuldeiser om het faillissement van een turbogeliquideerde rechtspersoon aan te vragen wegens het bestaan van een vordering ex artikel 2:9 BW. ${ }^{54}$ Omdat niet algemeen bekend is of decharge is verleend, blijft een dechargeverweer een risico dat een schuldeiser loopt bij de faillissementsaanvraag.

50. HR 27 januari 1995, ECLI:NL:HR:1995:ZC1631, NJ 1995/579 (APH/Söderqvist q.q.), r.o. 4.3 .

51. Vgl. Renssen 2013 en Hof Den Haag 2 juli 2015, ECLI:NL:GHDHA 2015:1846, JOR 2016/47 m.nt. S. Renssen.

52. Kamerstukken II $1980 / 81,16631,3$, p. 4.

53. Asser/Maeijer \& Kroeze 2-I* 2015/203; Polak \& Pannevis 2014, par. 5.3.2.1

54. Oppedijk van Veen 2006. 
Wel is het risico op decharge beperkt als de jaarrekening niet is vastgesteld en gepubliceerd. Vaststelling van de jaarrekening en decharge worden veelal behandeld tijdens dezelfde aandeelhoudersvergadering. Daarnaast zal een eventueel verleende decharge beperkte werking hebben als de jaarrekening niet is vastgesteld en gepubliceerd en als niet voldaan is aan de boekhoudplicht, omdat decharge uitsluitend verleend wordt voor gegevens die uit de jaarrekening blijken of anderszins aan de algemene vergadering van aandeelhouders bekend zijn gemaakt. 55

Tot slot is de (weliswaar beperkte) bewijslast van een schuldeiser een groot nadeel. In de regel heeft de schuldeiser geen inzicht in de administratie en andere interne stukken van de rechtspersoon. Als de rechtspersoon ook de jaarstukken niet heeft gepubliceerd, heeft de schuldeiser in beginsel in het geheel geen zicht op de financiën van de rechtspersoon. Voor een individuele schuldeiser is het daarom erg moeilijk om aannemelijk te maken dat sprake is van onbehoorlijk bestuur, ten gevolge waarvan de rechtspersoon schade heeft geleden. Het zal daarom regelmatig voorkomen dat het niet mogelijk is om een vordering ex artikel 2:9 BW aannemelijk te maken, terwijl de boekhouding van de rechtspersoon niet op orde is en/of de jaarstukken niet (tijdig) zijn gepubliceerd.

\subsection{Pauliana}

Dat de rechtsvordering tot vernietiging van een rechtshandeling op grond van schuldeiserspauliana op zichzelf geen bate van de rechtspersoon is, is geen nadeel voor schuldeisers van een turbogeliquideerde rechtspersoon. Een schuldeiser kan ook na turboliquidatie een beroep doen op schuldeiserspauliana. Een paulianeuze rechtshandeling kan worden vernietigd door een buitengerechtelijke verklaring en door een rechterlijke uitspraak. ${ }^{56}$ Als de rechtshandeling is vernietigd, bestaat de (ten onrechte) turbogeliquideerde rechtspersoon nog steeds omdat de vernietiging terugwerkt tot het tijdstip waarop de rechtshandeling is verricht. ${ }^{57}$

Overigens kan het aangaan van een paulianeuze rechtshandeling ook leiden tot aansprakelijkheid van de bestuurder die een dergelijke rechtshandeling heeft bewerkstelligd of toegelaten en wist of had moeten weten dat het gevolg hiervan zou zijn dat de rechtspersoon zijn verplichtingen niet na zou kunnen komen en ook geen verhaal zou bieden voor de geleden schade. ${ }^{58}$ Een individuele schuldeiser kan - als alternatief voor de aanvraag van het faillissement van de turbogeliquideerde rechtspersoon - daarom ook de bestuurder aansprakelijk stellen op grond van artikel 6:162 BW wegens zijn betrokkenheid bij de paulianeuze rechtshandeling.

55. HR 10 januari 1997, ECLI:NL:HR:1997:ZC2243, NJ 1997/360 (Staleman/Van de Ven), r.o. 3.4.1; HR 25 juni 2010, ECLI:NL:HR: 2010:BM2332, NJ 2010/373 (De Rouw/Dingemans q.q.), r.o. 3.4.

56. Art. $3: 49 \mathrm{BW}$.

57. Art. 3:53 lid $1 \mathrm{BW}$

58. HR 8 december 2006, ECLI:NL:HR:2006:AZ0758, NJ 2006/659 (Ontvanger/Roelofsen), r.o. 3.5.
Nadat een schuldeiser een succesvol beroep heeft gedaan op schuldeiserspauliana, heeft de turbogeliquideerde rechtspersoon met terugwerkende kracht een bate en kan de schuldeiser het faillissement van de rechtspersoon aanvragen. Als een paulianeuze rechtshandeling is vernietigd door middel van een buitengerechtelijke verklaring, zal de faillissementsrechter conform het arrest APH/Söderqvist q.q. moeten beoordelen of summierlijk blijkt van feiten of omstandigheden die voldoende aannemelijk maken dat de rechtshandeling op terechte gronden is vernietigd. Voor een individuele schuldeiser is het alleen niet nodig om het faillissement aan te vragen, omdat een schuldeiser die een geslaagd beroep heeft gedaan op pauliana zijn vordering kan verhalen op de zaak die daardoor teruggegeven moet worden. ${ }^{59}$ Voor een individuele schuldeiser zou een faillissementsverzoek alleen maar nadelig zijn, omdat hij de opbrengst in faillissement moet delen met alle (boedel)schuldeisers van de rechtspersoon.

Het kan wel nadelig zijn voor een schuldeiser als de vordering wegens faillissementspauliana niet gezien wordt als bate van de rechtspersoon in de zin van artikel 2:19 lid 4 BW. Een schuldeiser heeft op grond van artikel 3:50 lid 2 BW niet de mogelijkheid om een rechtshandeling te vernietigen met een buitengerechtelijke verklaring ten aanzien van een registergoed, als inschrijving in de openbare registers heeft plaatsgevonden en niet alle partijen berusten in de vernietiging. De curator heeft deze mogelijkheid wel. ${ }^{60}$ Ook heeft de curator de mogelijkheid verplicht verrichte rechtshandelingen te vernietigen op grond van artikel $47 \mathrm{Fw}$, terwijl een schuldeiser deze mogelijkheid niet heeft. Tot slot noem ik als verschil tussen schuldeiserspauliana en faillissementspauliana nog de mogelijkheid die de curator heeft om een beroep te doen op de Garantstellingsregeling curatoren. ${ }^{61}$ Vanwege deze verschillen tussen schuldeiserspauliana en faillissementspauliana kan het in het voordeel van een schuldeiser zijn als een vordering wegens faillissementspauliana gezien wordt als bate in de zin van artikel 2:19 lid 4 BW.

\section{Taak van de wetgever?}

Er kleven diverse nadelen aan de besproken alternatieven voor de aanvraag van het faillissement van een turbogeliquideerde rechtspersoon wegens het bestaan van een vordering ex artikel 2:248 BW of van een vordering tot vernietiging van een rechtshandeling wegens faillissementspauliana. De rechtsonzekerheid en rechtsongelijkheid die zijn ontstaan doordat twee hoven de artikel 2:248 BW-vordering in het licht van artikel 2:19 lid $4 \mathrm{BW}$ verschillend kwalificeren, worden dus niet weggenomen met de besproken alternatieven. In ieder geval in het arrondissement Amsterdam is het mogelijk dat bestuurders van een turbogeliquideerde rechtspersoon wegkomen met onbehoorlijk bestuur. Ten behoeve van de rechtsgelijkheid en rechtszekerheid en om te voorkomen dat misbruik gemaakt

59. Asser/Hartkamp \& Sieburgh 6-III 2014/600.

60. Wessels 2013, nr. 3031.

61. Art. 43 lid 6 Fw jo. art. 2:138 lid 10 BW. Zie voor deze en ook voor andere niet-genoemde verschillen Wessels 2013, nr. 3031. 


\section{Maandblad}

Ondernemingsrecht

wordt van turboliquidatie, kan de wetgever duidelijkheid scheppen door artikel 2:19 lid 4 BW aan te scherpen.

Nethe heeft voorgesteld om turboliquidatie uitsluitend mogelijk te maken als de rechtspersoon geen 'vermogen of andere rechtsbetrekkingen' meer af te wikkelen heeft. ${ }^{62}$ Hiermee wordt het begrip 'baten' in artikel 2:19 lid 4 BW duidelijker en breder en zou de wettekst meer aansluiten bij het normale spraakgebruik en de jurisprudentie. Mijns inziens bestaat dan nog steeds geen duidelijkheid over de vordering ex artikel 2:248 BW, de Peeters/Gatzen-vordering en de paulianavordering. Ik stel daarom voor om artikel 2:19 lid $4 \mathrm{BW}$ als volgt te formuleren:

'Indien de rechtspersoon op het tijdstip van zijn ontbinding geen vermogen of andere rechtsbetrekkingen meer af te wikkelen heeft, houdt hij alsdan op te bestaan. In dat geval doet het bestuur of, bij toepassing van artikel 19a, de Kamer van Koophandel, daarvan opgaaf aan de registers waar de rechtspersoon is ingeschreven. Een rechtspersoon houdt niet op te bestaan indien aannemelijk is dat de curator, indien het faillissement van de rechtspersoon zou worden uitgesproken, baten voor de boedel kan realiseren.'

Turboliquidatie is ontbinding zonder vereffening omdat er niets is om te vereffenen. Het heeft geen zin om het faillissement van een turbogeliquideerde rechtspersoon aan te vragen als er voor de curator geen baten te verdelen zijn onder de gezamenlijke schuldeisers. ${ }^{63} \mathrm{Als}$ een paulianavordering, een Peeters/Gatzen-vordering of een vordering ex artikel 2:248 BW slaagt, is dat wel het geval. De aanbevolen formulering schept duidelijkheid en doet recht aan het doel van turboliquidatie en het faillissement.

\section{Conclusie}

In de rechtspraak is verschillend geoordeeld over de vraag of een vordering op grond van artikel 2:248 BW valt onder het begrip baten van de rechtspersoon zoals bedoeld in artikel 2:19 lid 4 BW. Deze onduidelijkheid kan ook bestaan ten aanzien van de Peeters/Gatzen-vordering en de paulianavordering. Een schuldeiser kan niet in alle arrondissementen het faillissement van een turbogeliquideerde rechtspersoon aanvragen als er sprake is van genoemde vorderingen. Een schuldeiser van een turbogeliquideerde rechtspersoon heeft wel andere mogelijkheden om zijn vordering te verhalen op bestuurders, derden aansprakelijk te stellen of het faillissement van de turbogeliquideerde rechtspersoon aan te vragen. Mede vanwege de gebrekkige bewijspositie van een schuldeiser volstaan deze alternatieven niet altijd in de strijd tegen misbruik van turboliquidatie. Daarom is het omwille van de rechtszekerheid en om misbruik van turboliquidatie tegen te gaan noodzakelijk om in de wet op te nemen dat een rechtspersoon niet ophoudt te bestaan als aannemelijk is dat de curator in faillissement baten voor de boedel kan realiseren.

62. Nethe 2016, p. 441 en 442.

63. Zie ook HR 18 december 2015, ECLI:NL:HR:2015:3636, r.o. 4.7.1 en par. 3.21 van de conclusie van A-G Timmerman bij dit arrest. 